\title{
WAREHOUSE DESIGN FOR ELECTRICAL EQUIPMENT MANUFACTURER: A CASE STUDY
}

\author{
Anh Nam Diep, Linh Y Thai and Mai-Ha Phan* \\ Department of Industrial Systems Engineering, \\ Ho Chi Minh University of Technology (HCMUT), \\ Vietnam National University, Ho Chi Minh City, Vietnam \\ *Corresponding Author
}

\begin{abstract}
Systems engineering approaches utilize systems thinking principles in complex projects such as computer chip design, robotics. However, this technique is also useful in proposing solutions to logistics systems, namely warehouse design. This paper will apply systems engineering in designing finished product warehouse for an electrical equipment manufacturer. Our results suggest a completed design addressing the needs of stakeholders and all likely aspects of the systems are considered and integrated into a whole. These solutions propose an optimal design for warehouse simultaneously utilize available resources of the manufacturer.
\end{abstract}

Keywords: warehouse design, systems engineering.

Cite this Article: Anh Nam Diep, Linh Y Thai and Mai-Ha Phan, Warehouse Design for Electrical Equipment Manufacturer: A Case Study. International Journal of Mechanical Engineering and Technology. 11(7), 2020, pp. 51-71.

https://iaeme.com/Home/issue/IJMET?Volume=11\&Issue=7

\section{INTRODUCTION}

Systems engineering is a management technology to assist and support policy making, planning, decision making, and associated resource allocation or action deployment. It accomplishes this through quantitative and qualitative formulation, analysis, and interpretation of the impacts of action alternatives with reference to users' needs, values and institutional perspectives [1]. One way to understand the motivation behind systems engineering is to see it as a method, or practice, to identify and improve common rules that exist within a wide variety of systems. Keeping this in mind, the principles of systems engineering - holism, emergent behavior, boundary, et al. - can be applied to any system, complex or otherwise, provided systems thinking is employed at all levels [2].

Electricity is one of the energy pillars of every nation, takes the part of the lifeblood of modern industries. The development of any industry requires the expansion of the national power system as a prerequisite. Along with the shift of production to Vietnam in recent years 
because of macroeconomic impacts, the demand for electricity for production is increasing and it is one of the biggest demands that the power industry has been very interested in.

Considering the consumption rate of electricity in 2019, Southern Vietnam witnessed the use of over $50 \%$ of the total power demand. While the figure for electricity consumption in the North is nearly $40 \%$ and in Central, it is nearly $10 \%$. In terms of current power supply, nearly $60 \%$ of suppliers situate mainly in the North and the Central, the South can only generate less than $40 \%$ of itself. The power transmission system is said to be unable to meet. Electricity supply systems should be continually expanded and upgraded.

In this paper, systems engineering methodology is applied to design the finished product warehouse of an electrical equipment manufacturer, which wants to expand its production capacity to meet the need of expanding the national electricity grid. This requires the manufacturer to comprehensively develop its production capacity, distribution, and storage systems.

\section{LITERATURE REVIEW}

Logistics is one of the strong growing industries today. According to Christopher (2016), Logistics is defined as the process of strategically managing the procurement, movement and storage of materials, parts and finished inventory (and the related information flows) through the organization and its marketing channels in such a way that current and future profitability are maximized through the cost-effective fulfilment of orders [3]. Logistics deals with the planning and control of material flows and related information in organizations, both in the public and private sectors. Broadly speaking, its mission is to get the right materials to the right place at the right time, while optimizing a given performance measure and satisfying a set of constraints (Ghiani et al., 2004) [4].

In the logistics system, there are many studies focusing on warehouses. Good warehouse management will greatly assist businesses in matters related to reducing wastage or loss of goods and increasing capital efficiency. Therefore, studies often focus on issues such as: How can warehouse managers deal with a large volume of goods and raw materials in an enterprise, How to ensure the smooth operation of import and export activities, limit the amount of inventory but still provide the necessary amount of goods for important activities... These studies focus on addressing the arrangement of goods, locating goods in warehouses, arranging shelves; methods of preserving goods, the process of importing and exporting goods, and organizing the management of goods and books in warehouses ...

A warehouse is a point in the supply chain where raw materials, work-in-process (WIP), or finished goods are stored for varying lengths of time. Warehouse has some main functions:

- Receiving,

- Storage,

- Move goods from storage areas to where they are needed. [6]

Based on these main functions, warehouse operation process can be divided into 2 parts: internal and external processing as Table 1 lists below [7]. Distinguishing between internal and external processing showed that warehouse is a system of internal operations such as receiving, sorting, packaging, and internal storage along with external operations showing the correlation between the system and eco-environment of the supply chain in which warehouse is the key operating point. In this research, the authors applied systems engineering in designing warehouses in the manufacturing environment of the electrical equipment manufacturer. 
Table 1 Distinguished warehouse processing

\begin{tabular}{ll}
\hline \multicolumn{1}{c}{ Internal processing } & \multicolumn{1}{c}{ External processing } \\
\hline Receiving & Order and receiving \\
Quality inspect and control & Delay receiving \\
Pick up and packaging & Sorting and collecting \\
Storage & Packaging and shipping \\
& Importing \\
& Cross-docking \\
\hline
\end{tabular}

Warehouse management is not a simple task, it requires technical as well as scientific organization to help activities related to goods in the warehouse go smoothly. Traditionally, warehouse managers need to be proficient in a lot of operations, from arranging, preserving goods and supplies, to performing tasks related to importing, exporting and planning goods. The first is the arrangement stage, there are many people feel confused when entering the warehouse because the amount of goods is too much but do not know where to put. The arrangement of goods plays an important role to help the process of finding, transporting as well as importing and exporting goods in the warehouse be conducted more quickly and at the same time ensure the convenient control goods export. Not only that, the scientific arrangement of goods also contributes to save storage area. Next is the periodical inventory which determines the actual quantity of goods in the warehouse compared to the books and records of goods; inspect the quality of the goods (identify damage or deterioration of goods). This is also an important activity to ensure the continuous circulation of goods, avoid being worn and torn or reducing use value. Ensuring warehouse arrangement and inventory are the first two elements of an effective warehouse management method.

Warehouse design includes three basic categories: facilities, operation process and management method [5]. According to Felix Geuken et. al. (2017) [8], 8-step warehouse design process for fast-growing factories is based on practical conditions and planned into 3 stages to develop ideas, specific modules are as follows (Fig.1). This process is

Stage 1: Identify warehouse location in the business environment, needed SKU, current storage capacity and future expansion plan.

Stage 2: Consider current conditions of equipment and their impact on warehouse operation, simultaneously integrate data from Stage 1 . Thence, propose general capacity parameters of the warehouse.

Stage 3: Propose design solutions and standards to evaluate and select the most suitable alternative to warehouse conditions. This sequence will be applied in Engineering development. 


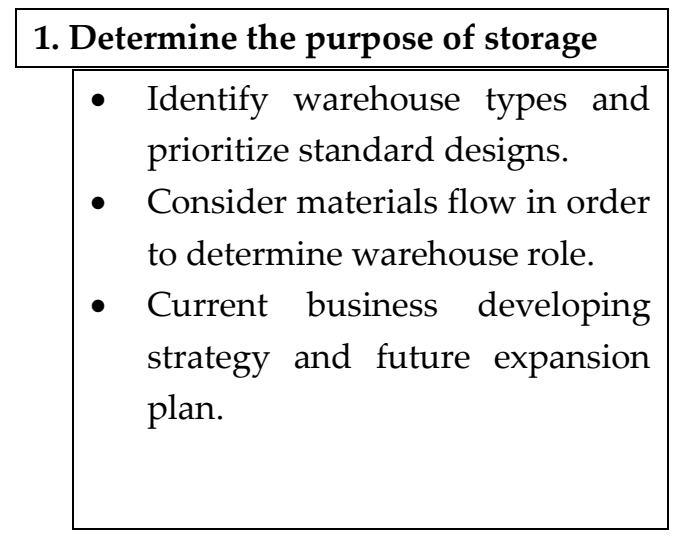

\begin{tabular}{l}
$\begin{array}{l}\text { 2. Construct warehouse operation flow } \\
\text { chart }\end{array}$ \\
\begin{tabular}{|l|l|}
\hline - Draw materials flow chart. \\
Observe and determine key \\
warehouse operations.
\end{tabular} \\
\hline
\end{tabular}

3. Determine store keeping unit (SKU)

- Determine SKU used in warehouse is considered in step 2.

\section{Analysis current demands and forecast future needs}

- Consider current demands and future developing scenario related to expansion plan is studied in step 1 .

- Analysis how identified operations in step 2, SKU in step 3 affect future developing scenarios.

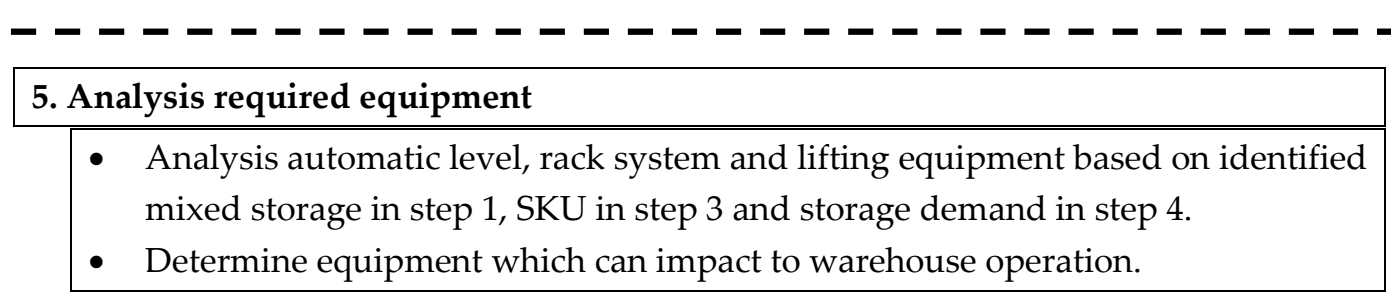

6. Space planning
$\begin{aligned} & \text { Determine areas for identified operations in step } 2 \text { based on developing scenarios } \\ & \text { in step } 4 \text { and number of required storage locations for identified equipment in } \\ & \text { step } 5 .\end{aligned}$

\section{Warehouse layout planning}

- Plan layout structure and analysis storage capacity, sources of emissions, material flow, flexible ability in changeable plans, future expansion and cost structure.

\footnotetext{
- - - - - - - - - - - - - - - - - - - - - - - - - -

8. Analysis integrated layout and determine feasible solutions

- Evaluate layouts identified in step 7 and design standards in step 1, thence, propose feasible solutions.
}

Figure 18 -step visual process of developing warehouse systems for fast-growing factories

\section{PROBLEM STATEMENT}

ABC Company is one of the leading providers of equipment for electrical infrastructure in Vietnam. The 10-year plan estimated from 2020 to 2030, to meet the demand of expanding the national electricity grid and serve the industrialization process promoted nationwide, the factory needs to increase the output by $50 \%$ compared to the current production capacity. This 
requires the factory to have comprehensive development of the manufacturer in terms of production capacity, storage systems, and distribution.

At present, the manufacturer has only a temporary warehouse with a roof in an area of about $480 \mathrm{~m}^{2}$. At its peak - April 2019 - with about 545 pallets of goods, the Warehouse Department had to arrange goods disorderly and utilize all the vacancies in the warehouse optimally. This made it difficult to move and tally in the warehouse. The current situation is inherently unable to meet the current needs of the factory. If the future production capacity increases, the current storage space will be more and more shortage. Therefore, the balance of production and storage will inevitably be difficult and affect plant productivity.

This is the main reason in addition to other auxiliary factors such as the demand to improve the quality of goods storage, protect the finished products from collisions during the transport process. This is also the premise for the Board of Directors of the manufacturer to make a real determination in deploying the construction of a new system of Electrical Equipment Finished Products Warehouse on the existing vacant land of the factory.

\section{NEEDS ASSESSMENT}

\subsection{Current State}

The factory has a total area of about $10,450 \mathrm{~m}^{2}$, the current construction area is about $6,000 \mathrm{~m}^{2}$ divided into 04 workshops as below:

- Measurement Laboratory $\left(720 \mathrm{~m}^{2}\right)$,

- Manufacturing - Assembly Workshop $\left(1,820 \mathrm{~m}^{2}\right)$,

- Electrical Panel Factory $\left(950 \mathrm{~m}^{2}\right)$,

- Repair - Maintenance Workshop $\left(1,140 \mathrm{~m}^{2}\right)$.

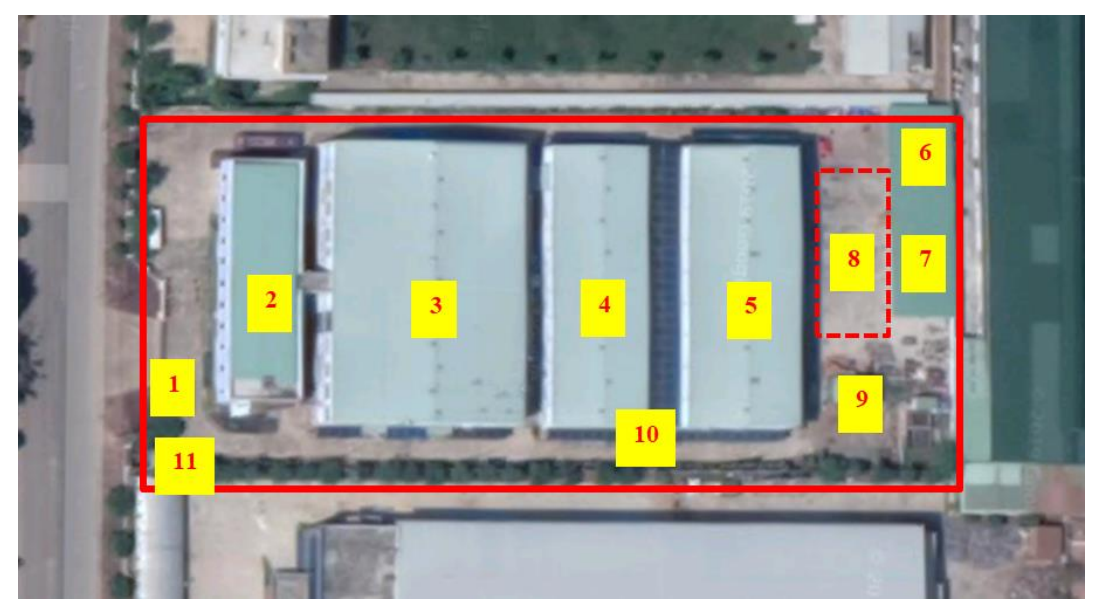

(1) Main gate - Security house; (2) Measurement Laboratory; (3) Manufacturing - Assembly workshop; (4) Cabinet - Electrical Panel workshop; (5) Repair - Maintenance workshop; (6) Chemical warehouse; (7) Temporary warehouse; (8) Planned warehouse location; (9) The garbage house; (10) Fire-fighting pumping station; (11) Power station.

Figure 2 The aerial photo of electrical equipment manufacturer and workshops

Figure 2 shows the aerial photo of electrical equipment manufacturer and workshops.

The existing warehouse is partially covered sufficient space of the entire products. This leads to a few problems during the peak production season.

- Conservation of product quality before delivery to customers: there are risks such as rust on accessories and product joints when carelessly stored that can indirectly cause unintended consequences for customers when they install non-standard equipment 
(there are latent defects inside) because it can cause fire and explosion when the electrical systems are operating. This affects the company's reputation.

- Wooden frames used to package products put outside can lead to being decayed. The improper stack can break the frame and directly affect the inside products.

- Due to the lack of planning, at peak time, goods are arranged disorderly without leaving aisles and classifying. This leads to difficulty in tallying, which can cause confusion and omissions and waste time in tallying and counting.

\subsection{Causes and Solutions}

After observing and identifying the problem, the authors discussed with relevant divisions and identified a number of particular causes:

- The warehouse of the factory is a temporary warehouse with a roof which is not a real finished product warehouse. In the past, when the factory was established, the factory has a small production scale and quick supply to the market so products were only stored within a day, almost shipped right after production. Along with the continuous development of the factory, they have had larger orders for key construction projects, which led to an increase in production capacity and higher needs in storage.

- Goods exposes to the environment may cause tear to products, resulting in collisions between packages during transportation. This also makes products damage and unsafe.

- Because there is no official warehouse, the warehouse arrangement depends on the management experience of the storekeeper and warehouse staff. There is also no shelf equipped so goods are often put on the ground. With a large number of pallets arranged disorderly will affect and make it difficult to tally.

Previously, the Board of Management considered outsourcing to save costs and avoid affecting production, but encountered some reasons:

- Non-factory storage area makes it difficult to move and control.

- Warehouses in the area of Tan Phu Trung Industrial Park are mostly old renovated factories - not following the original, outdated construction, not suitable for modern transport facilities, and no guarantee of safety conditions.

The construction of a new warehouse for the company is needed to improve product storage quality and warehouse operating conditions, contribute to the overall capacity of the plant future growth.

\subsection{Stakeholders Survey}

System design will relate to investors, suppliers, customers and system operators. With the finished products warehouse for the electrical equipment manufacturer, there will be some stakeholders listed in Table 2.

Table 2 Identify stakeholders, features and potential impacts on system

\begin{tabular}{|c|c|c|}
\hline Stakeholders & $\begin{array}{c}\text { Features } \\
\end{array}$ & Impacts \\
\hline $\begin{array}{l}\text { Company } \\
\text { Leadership }\end{array}$ & $\begin{array}{l}\text { - Play the role of investor, } \\
\text { - Make important decisions, } \\
\text { - Set development directions for } \\
\text { the organization and make budget } \\
\text { decisions. }\end{array}$ & $\begin{array}{l}\text { - Determine contraints, } \\
\text { - Receive the final design, } \\
\text { - Put the system into practice. }\end{array}$ \\
\hline $\begin{array}{l}\text { Warehouse and } \\
\text { Material } \\
\text { Department }\end{array}$ & $\begin{array}{l}\text { - Directly operate the system, } \\
\text { - Materials and Products storage } \\
\text { management, } \\
\text { - Know the principles of storage, }\end{array}$ & $\begin{array}{l}\text { - Direct department which uses and } \\
\text { manages the system, } \\
\text { - Receive information from the Sales } \\
\text { Team - finished product input }\end{array}$ \\
\hline
\end{tabular}




\begin{tabular}{|c|c|c|}
\hline & $\begin{array}{l}\text { preservation and transfer of } \\
\text { products. }\end{array}$ & $\begin{array}{l}\text { information, } \\
\text { - Receive finished products from the } \\
\text { Production Department based on order, } \\
\text { - Export finished products to the } \\
\text { Shipping Team as ordered. }\end{array}$ \\
\hline $\begin{array}{l}\text { Operation } \\
\text { Department }\end{array}$ & $\begin{array}{l}\text { - Produce and know products } \\
\text { features. } \\
\text { - Packaging. }\end{array}$ & $\begin{array}{l}\text { - Produce products, } \\
\text { - Determine packaging method. }\end{array}$ \\
\hline $\begin{array}{l}\text { Sale Team - } \\
\text { Planning } \\
\text { Department }\end{array}$ & $\begin{array}{l}\text { - The department directly works } \\
\text { with customers and issues orders } \\
\text { to the production department for } \\
\text { processing, } \\
\text { - Know the customer information } \\
\text { and types of products needed, } \\
\text { - Estimate future productivity and } \\
\text { future expansion needs. }\end{array}$ & $\begin{array}{l}\text { - Exploiting customers, proposing } \\
\text { orders, } \\
\text { - Support inventory counting and tally } \\
\text { in storage. }\end{array}$ \\
\hline $\begin{array}{l}\text { Shipping Team - } \\
\text { Planning } \\
\text { Department }\end{array}$ & $\begin{array}{l}\text { - Know the delivery process from } \\
\text { the factory to the customer, } \\
\text { - Get direct delivery orders from } \\
\text { the Sales Team. }\end{array}$ & $\begin{array}{l}\text { - Get finished products for shipping, } \\
\text { - Support tally on delivery. }\end{array}$ \\
\hline
\end{tabular}

Stakeholders requirements play an important role in design orientation, any requests and concerns are received and dealt later. Table 3 shows Stakeholders requirements document.

Table 3 Stakeholders requirements document

\begin{tabular}{|c|c|}
\hline Stakeholder & $\begin{array}{r}\text { Requirements } \\
\end{array}$ \\
\hline Company Leadership & $\begin{array}{l}\text { Final result: Finished Products Warehouse needs to be professionally organized, } \\
\text { clean and safe, } \\
\text { The total investment of less than } 5 \text { billion VND, } \\
\text { Long-term use (10 years), } \\
\text { Short construction time ( } \leq 3 \text { months), } \\
\text { Construction process does not affect the operation of the manufacturer. }\end{array}$ \\
\hline $\begin{array}{l}\text { Production } \\
\text { Department }\end{array}$ & $\begin{array}{l}\text { Quickly tally and store. } \\
\text { Simply receiving - shipping procedures. }\end{array}$ \\
\hline $\begin{array}{l}\text { Warehouse } \\
\text { Department }\end{array}$ & $\begin{array}{l}\text { Manage inventory status easily (know the quantity, type, location in the } \\
\text { warehouse). } \\
\text { Machinery and tools (if any) are easy to manipulate and use. } \\
\text { Warehouse procedure is quick and effective. } \\
\text { Warehouse design is stable and safe to use. } \\
\text { Daily inventory counting time is } 10 \text { minutes / time. } \\
\text { Reduce the damage rate of wooden protective frames used to cover for products } \\
\text { at least } 50 \% \text {. }\end{array}$ \\
\hline Delivery Team & $\begin{array}{l}\text { Simple and quick delivery procedures. } \\
\text { Products are delivered must ensure intact packing condition, quality, right } \\
\text { quantity and type. } \\
\text { Operating procedures must save product search time. } \\
\text { Time of delivery process, from receipt of goods request to complete delivery on } \\
\text { truck is less than } 60 \text { minutes. }\end{array}$ \\
\hline $\begin{array}{l}\text { Sales, Planning and } \\
\text { other Departments }\end{array}$ & $\begin{array}{l}\text { Inventory status is determined with high reliability, fast and simple. } \\
\text { There is fast inventory process. } \\
\text { Data is backed up in real time on the company data system, easily accessed by } \\
\text { warehouse staffs if needed for comparison. }\end{array}$ \\
\hline
\end{tabular}

\section{CONCEPTUAL DESIGN}

\subsection{Operation Analysis}

The Finished Product Warehouse must have five functions based on the round trip of the finished product in the warehouse of the factory: Receiving, Put-away, Storage, Picking and 
Delivery. The main operation of the Finished Products Warehouse and implementation steps are listed below.

\section{Receiving}

Products produced at the workshops of the Production Department will be inspected by the Quality Department. After that, the product will be conveyed to the finished product warehouse. The Warehouse Department will confirm the quantity, product type, and receive them into the warehouse for storage. The important requirement at this stage is the strict procedure to ensure that the product quantity and type are not misleading. In the Finished Product Warehouse, some steps required to receive products:

- Receive the storage order,

- Tally finished products,

- Update to inventory data,

- Sign the goods delivery note;

\section{Put-away}

After warehouse manager accepts to receive inventory from the production department, the product will be considered and sorted into the appropriate position to ensure reasonable and optimal arrangement. This sorting process aims to optimize product storage, make it easy to find when needed, shorten the time to search for products as well as the distance to travel to pick up products from the placement. Three steps required to put goods away:

- Locate the vacant position by software and visually check,

- Update location to software,

- Move the finished product to the available shelf cell;

\section{Storage}

After determining the proper location, the product will be moved into shelf-cell in the warehouse. When the product is in stock until it is delivered to the receiving parties, it must ensure that the product is kept safe and the product quality including internal and visual specification is not affected during storage.

\section{Picking}

Upon receipt of a delivery request, the warehouse manager checks the amount of finished product stored in the warehouse whether meets the order, then determines the location of the products to be moved, and move to a predetermined assembly location. This process needs to be fast, accurate, and the transport of products must be safe. Some steps required to pick:

- Receive exporting order,

- Check inventory in software,

- Confirm sufficient response,

- Pick the goods from the shelves,

- Deliver goods to the loading bay.

\section{Delivery}

The product is transported to the loading bay, then will be transferred to the truck, handed over to the customer warehouse. This process requires fast, safe, complete legal procedures for transport and management. Some steps required to delivery:

- Tally finished products,

- Confirm status of the finished products, 
- Load goods to truck,

- Sign the delivery note.

\subsection{Functional Analysis}

The design orientation is based on the requests of the relevant departments (stakeholder requirements) to determine the implementation direction and external aspects that may affect the system.

Table 4 shown as below lists stakeholder requirements and provides design directions from stakeholder requirements and system performance analysis.

Table 4 Stakeholders design requirements

\begin{tabular}{ll}
\hline Stakeholders & \multicolumn{1}{c}{ Requirements } \\
& $\begin{array}{l}\text { The finished product - warehouse system } \\
\text { performing professional, clean, safe, plays the } \\
\text { presentation role of the company to introduce to } \\
\text { customers. }\end{array}$ \\
& The total investment for the warehouse is about \\
Company & VND 5 billion. \\
Leadership & Construction period is short - about 03 months. \\
& The construction process of the warehouse does not \\
& affect the current occupation of the factory. \\
& $\begin{array}{l}\text { Fast tally, quick confirmation and warehousing. } \\
\text { Quick and simple delivery and warehousing }\end{array}$ \\
& procedure. \\
Production & Ability to store an average of 70 large products per \\
Department & day, 100 small products per day.
\end{tabular}

Manage inventory status easily (know the quantity, type, location in the warehouse).

Machinery and tools (if any) are easy to manipulate

Warehouse and use.

Department

Warehouse procedure is quick and effective.

Warehouse design is stable and safe to use.

Daily inventory counting time is 10 minutes/time.

Reduce the damage rate of wooden protective frames used to cover for products at least $50 \%$.

- Warehouse design must be compatible with the conditions of the factory, also economical, take advantage of available resources to save budget and operating costs.

Choose a reputable construction contractor.

Choose a reasonable starting time to avoid affecting the factory operation.

Building a process of stock in / out, rational and optimal warehouse operation. Apply current technology of management to the process.

Warehouse management software has a function of visually monitoring inventory status, identifying each item in the warehouse containing certain types of items.

Machinery is compact, easy to use, has a process of training, warehouse staffs must by trained thoroughly before putting into use.

There must be reasonable and optimal warehouse process.

Warehouse construction materials must by firmly and safe.

There are simple and quick delivery procedures. Products are delivered must ensure intact packing condition, quality, right quantity and type.

Delivery Team Operating procedures must save product search time.

Time of delivery process, from receipt of goods request to complete delivery on truck is less than 60 minutes.

Inventory status is determined with high reliability, fast and simple.

Sales, Planning There is fast inventory process.

and other Data is backed up in real time on the company data Departments system, easily accessed by warehouse staffs if needed for comparison.

- There is reasonable and optimal warehouse operating procedure.

- Warehouse has close structure, against dust, and other effects of the environment, ensure the product quality during storage.

Warehouse management software (WMS) has the function of visually monitoring inventory status, identifying each item in the warehouse containing types of products, and amount. 


\subsection{Functional Baseline}

Based on the requirements of the stakeholders, after operating performance analysis steps to the addition of new steps or processes corresponding to the use of software and the application of modern warehouse management methods such as using barcode to identify on shelf-cell of product. A number of feasibility assessments and operational scenarios also have been developed to ensure the warehouse design can work in assumed scenarios such as urgent delivery followed customer requirements, in unexpected or periodical inventory checking, etc..

The collected data used to make basement for the functional baseline includes many forms - statistical data, hardcopy documents and actual recorded data based on expert method, current survey method and direct interview method. Depended on the collected data, the warehouse system is developed consisting of 06 main subsystem, there are 03 subsystems need to be designed including: Physical, Safety and Interface. Functional Baseline was built for the warehouse system shown in Figure 3.

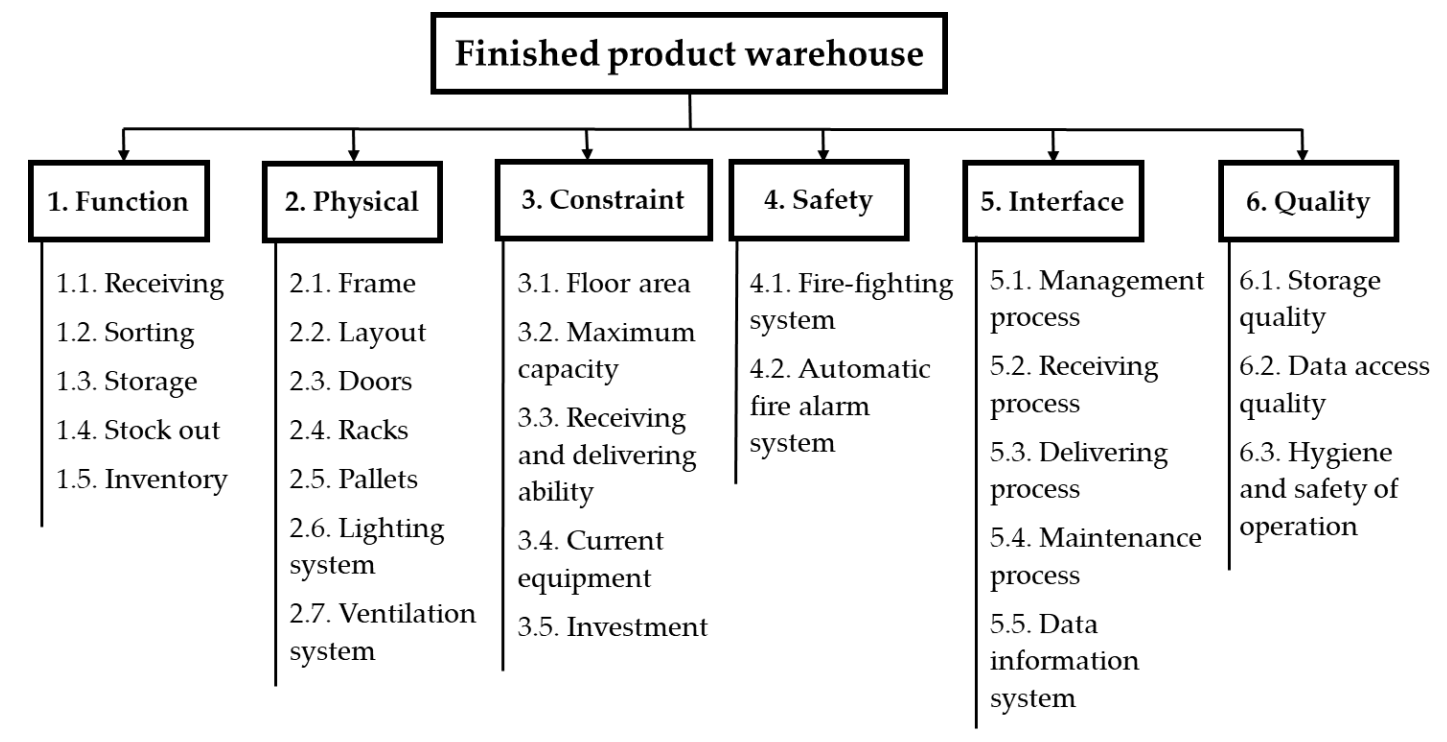

Figure 3 Functional Baseline of the finished product warehouse

And System Specification are shown Table 5.

Table 5 System Specification

\begin{tabular}{cl}
\hline Items & \multicolumn{1}{c}{ Specification Contents } \\
\hline System Name & \multicolumn{1}{c}{ Finished product warehouse of electrical equipment manufacturer } \\
\hline Sescription & $\begin{array}{l}\text { Total floor area is about } 1,000 \mathrm{~m}^{2} \\
\text { Investment capital is VND 5 billion } \\
\text { The warehouse is designed to contain the finished products of the electrical } \\
\text { equipment factory (capacitors, transformers, inverters), which can be } \\
\text { combined with some raw materials at the time of empty storage - about 50 } \\
\text { pallets of material. } \\
\text { Capacity of the warehouses as required by the Warehouse Department is } \\
\text { 1,000 PT-CT products; 1,000 medium voltage capacitors and 5,000 low } \\
\text { voltage CT products. } \\
\text { The warehouse has a solid construction structure. } \\
\text { There is a suitable lighting and ventilation system. } \\
\text { There are loading bays in both input and output doors according to the daily } \\
\text { capacity of the factory, and the carrying capacity of vehicles. } \\
\text { There is a packing area belong to management of Production Department, } \\
\text { office corner used by warehouse staffs, document storage, charging area of } \\
\text { forklifts. }\end{array}$ \\
\hline
\end{tabular}




\begin{tabular}{ll}
\hline \multicolumn{1}{c}{ Items } & \multicolumn{1}{c}{ Specification Contents } \\
\hline & Warehouse doors are designed in accordance with forklifts moving goods in \\
and out of the warehouse. \\
Ensuring the safety of fire prevention and protection, there is a fire automatic \\
alarm system, automatic fire-fighting system - auto hanging foam fire- \\
extinguishers or wet sprinklers, adequate number of fire extinguishers and \\
indoor hydrants. \\
There are procedures of warehouse managing, maintaining and operating. \\
There is a warehouse management software - WMS. \\
The warehouse must take advantage of available equipment of the plant such \\
as fire pump system, electrical system, forklift truck, barcode marking \\
machine ... \\
\hline The Finished Product Warehouse has 05 main functions including: Receiving, \\
Arranging, Storage, Delivery and Handover. \\
The ability to receive an average of 70 large products per day, 100 medium \\
voltage products per day. \\
Daily inventory checking period is about 10 minutes / time \\
Time of delivery process - from receipt of delivery request to complete \\
delivery on truck less than 60 minutes. \\
Data is backed up in real time on the company's website system, easily \\
accessible if needed for reconciliation when inventory. \\
Reduce the rate of damaged wooden frames containing finished products by at \\
least 50\%.
\end{tabular}

\section{PRELIMINARY DESIGN}

\subsection{Allocation Matrix}

Based on the above system specification table, there are 13 functional requirements of Finished Product Warehouse. The warehouse subsystem consists of 03 subsystems: Physical systems, Safety, and Interface.

- Physical systems include functions of physical structure such as: Construction structure, Layout, Doors, Steel-rack shelves, Pallets, Lighting system, and Ventilation system.

- Safety includes 02 items: Fire protection system, Automatic fire alarm system

- Interface includes the process of connecting between the relevant parts: Receiving process, Input and Output process, Delivery process, Maintenance process, Data information system.

The main functions of the Finished Products Warehouse, together operating in accordance, are presented in Figure 4.

To develop the subsystem of designed object, the data provided to support warehouse design includes a variety of types including: interview requirements mentioned in the direct interviews, input and output stock documents, local safety current industrial workshop design standards, etc... Therefore, they require many different approaches to apply these requirements in design practice. 
Warehouse Design for Electrical Equipment Manufacturer: A Case Study

\begin{tabular}{|c|c|c|c|c|c|c|c|c|c|c|c|c|c|c|}
\hline \multirow{2}{*}{ ALLOCATION MATRIX } & \multicolumn{7}{|c|}{ PHYSICAL } & \multicolumn{2}{|c|}{ SAFETY } & \multicolumn{5}{|c|}{ INTERFACE } \\
\hline & 1 & 2 & 3 & 4 & 5 & 6 & 7 & 8 & 9 & 10 & 11 & 12 & 13 & 14 \\
\hline 1. Total floor area is about $1,000 \mathrm{~m}^{2}$ & $x$ & $x$ & & $x$ & & $x$ & $x$ & $x$ & $x$ & $x$ & $x$ & $x$ & & \\
\hline 2. Investment capital is 5 billion VND & $x$ & $x$ & $x$ & $x$ & $x$ & $x$ & $x$ & $x$ & $\mathrm{x}$ & & & & & $x$ \\
\hline $\begin{array}{l}\text { 3. The finished product warehouse is designed to contain the finished } \\
\text { products of the electrical equipment factory (capacitors, transformers, } \\
\text { inverters), which can be combined with some raw materials at the time of } \\
\text { empty storage - about } 50 \text { pallets of material. }\end{array}$ & $x$ & $x$ & & $\mathrm{x}$ & $x$ & & & & & & & & & \\
\hline $\begin{array}{l}\text { 4. Capacity of the warehouses as required by the Warehouse Department } \\
\text { is 1,000 PT-CT products; } 1,000 \text { medium voltage capacitors and 5,000 low } \\
\text { voltage CT products. }\end{array}$ & & $x$ & & $\mathrm{x}$ & $x$ & & & & & $x$ & & $x$ & & $x$ \\
\hline 5. The warehouse has a solid construction structure. & $x$ & & $x$ & $\mathrm{x}$ & & & & & & & & & & \\
\hline 6. There is a suitable lighting and ventilation system. & & & & & & $\mathrm{x}$ & & & & & & & & \\
\hline $\begin{array}{l}\text { 7. There are loading bays in both input and output doors according to the } \\
\text { daily capacity of the factory, and the carrying capacity of vehicles. }\end{array}$ & & $x$ & $x$ & $\mathrm{x}$ & $\mathrm{x}$ & & & & & $\mathrm{x}$ & & $x$ & & \\
\hline $\begin{array}{l}\text { 8. There is a packing area belong to management of Production } \\
\text { Department, office corner used by warehouse staffs, document storage, } \\
\text { charging area of forklifts. }\end{array}$ & & $x$ & & & & & & & & & & & & \\
\hline $\begin{array}{l}\text { 9. Warehouse doors are designed in accordance with forklifts moving } \\
\text { goods in and out of the warehouse. }\end{array}$ & & $\mathrm{x}$ & $x$ & & & & & & & & & & & \\
\hline $\begin{array}{l}\text { 10. Ensuring the safety of fire prevention and protection, there is a fire } \\
\text { automatical alarm system, automatic fire-fighting system - auto hanging } \\
\text { foam fire-extinguishers or wet sprinklers, adequate number of fire } \\
\text { extinguishers and indoor hydrants. }\end{array}$ & & & & & & $\mathrm{X}$ & & $x$ & $\mathrm{x}$ & & $x$ & & $\mathrm{x}$ & \\
\hline $\begin{array}{l}\text { 11. There are procedures of warehouse managing, maintaining and } \\
\text { operating. }\end{array}$ & & & & & & & & & & $\mathrm{x}$ & $x$ & $\mathrm{x}$ & $x$ & \\
\hline 12. There is a warehouse management software - WMS. & & & & & & & & & & $\mathrm{x}$ & $x$ & $x$ & & $x$ \\
\hline $\begin{array}{l}\text { 13. The warehouse must take advantage of available equipment of the } \\
\text { plant such as fire pump system, electrical system, forklift truck, barcode } \\
\text { marking machine ... }\end{array}$ & & $\mathrm{X}$ & $\mathrm{x}$ & $\mathrm{x}$ & $\mathrm{x}$ & & & $\mathrm{x}$ & $\mathrm{x}$ & & & & & $\mathrm{x}$ \\
\hline
\end{tabular}

(1) Construction Structure; (2) Layout; (3) Doors; (4) Shelves; (5) Pallets; (6) Lighting System; (7) Ventilation System, (8) Fire Fighting System; (9) Fire Alarm System; (10) Receiving Stock Procedure; (11) Storage \& Audit Procedure; (12) Outputting Stock Procedure; (13) Maintenance Procedure; (14) Data Information System.

Figure 4 Allocation Matrix

$\begin{array}{lll} & \text { Method of Developing subsystems } & \\ \text { Current state survey } \\ \text { and calculation }\end{array}$

Figure 5 Method of development the subsystem

Design contents inlude many items related to many departments shown as Figure 5 many approaching ways to finish an accomplished explanation report submitted to factory's Board of Directors such as: amount of pallets, layout, fire-fighting, etc. Within the scope of the this 
paper, one approach was chosen with three subsystems that are closely related to each other in calculations and they are also common basis for designing warehouses includes: Pallets Layout - Racks.

According to [8], Felix Geuken and Louise Jager give us an overview of the steps needed to determine the design order, starts with determining store keeping unit - SKU (Step 3) to plan layout of the premises (Step 7) considered as one part of Preliminary Design shown as in Figure 6.

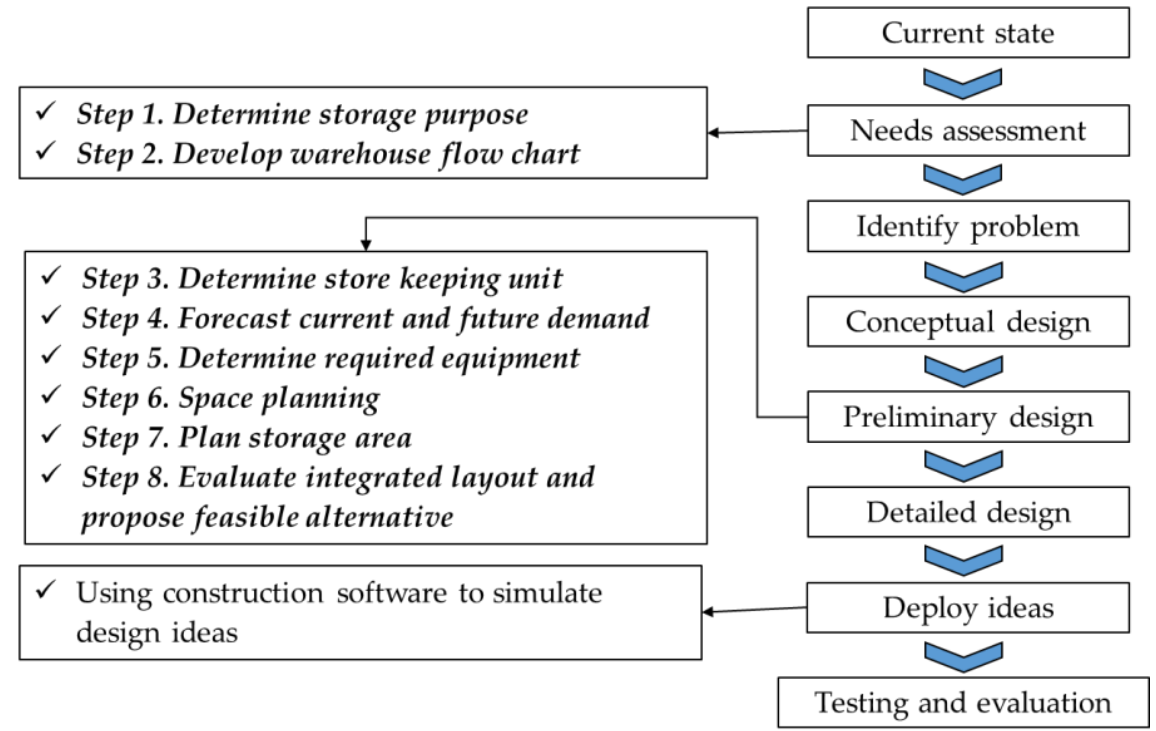

Figure 6 Warehouse design methodology applied in the paper

Table 6 Specification of finished product packaging procedure

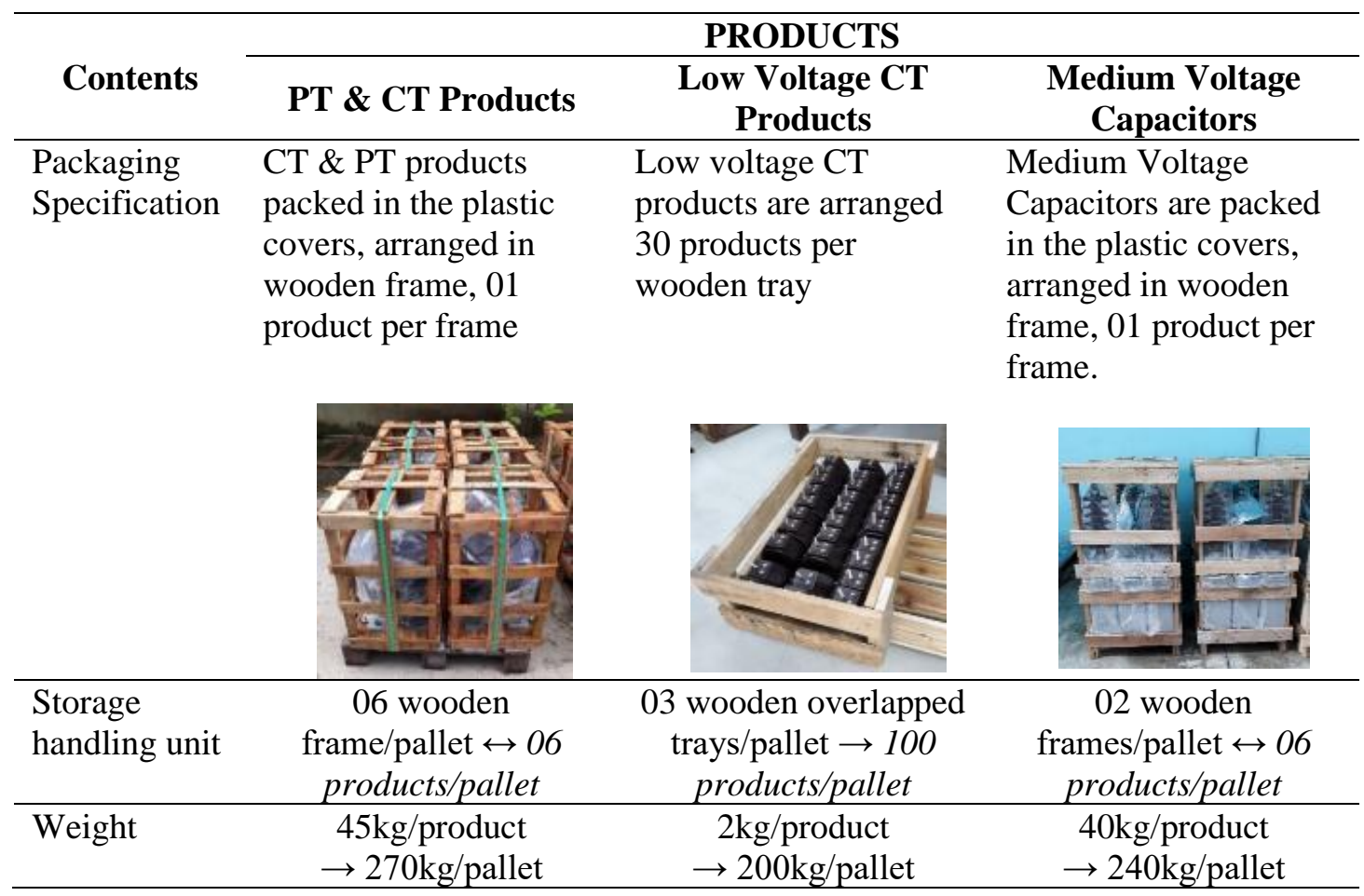




\subsection{Pallets}

Followed the above flowchart, then the storage handling units in the surveyed premise is identified and discussed. The current temporary storage mostly focuses on handling pallets, both in the flow to and from the warehouse, conducted by Packaging Team of Production Department will be occupied an area of the expected warehouse. Table 6 shows the product packaging specifications.

$$
\text { Amount of pallet }=\frac{\text { Amount of each type of finished products }}{\text { Amount of the finished products arranged in each pallet }}
$$

From the above formula, there is the table of the factory output within 03 years of 2017 , 2018, 2019 and estimated to 2020 presented in Figure 7 (Assigned pallet type have standard size of $1.2 \mathrm{~m} \times 1 \mathrm{~m} \times 0.154 \mathrm{~m}$, commonly used in the factory).

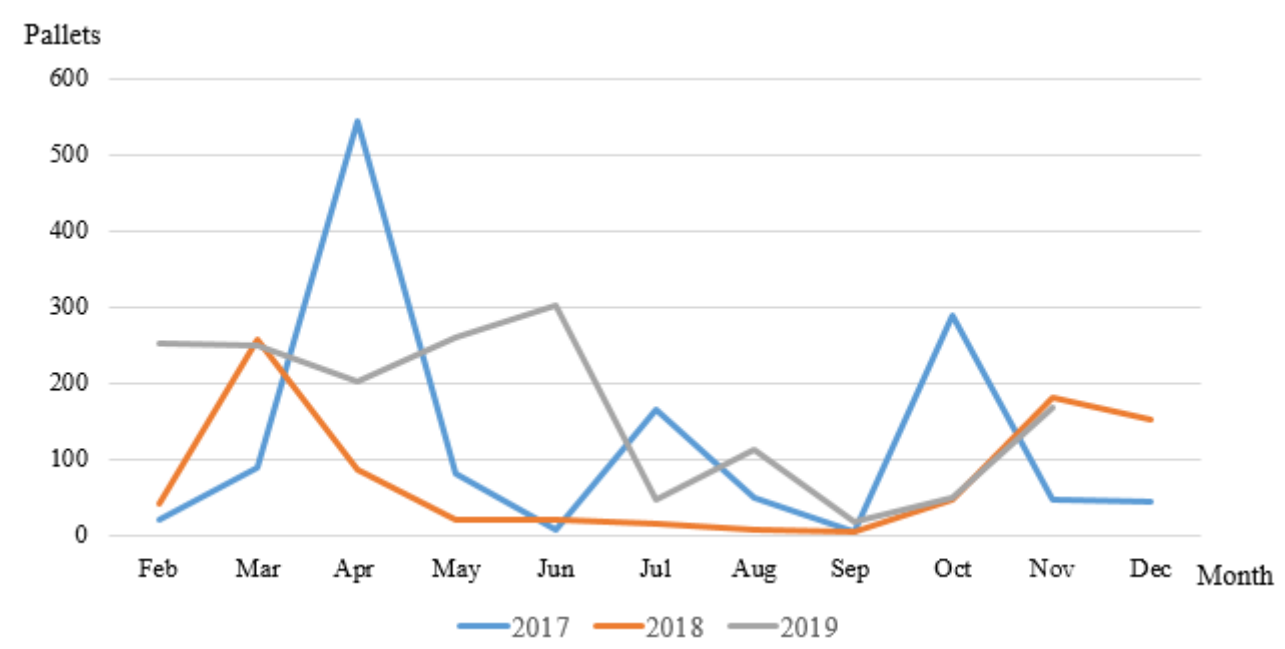

Figure 7 Outcome of the factory within $2017-2019$

Table 7 Peak-to-average ratio on stored pallets from 2017 to 2019

\begin{tabular}{cccc}
\hline Year & $\begin{array}{c}\text { Peak of the year } \\
\text { (pallets) }\end{array}$ & Average (pallets) & Peak to average \\
\hline Outcome 2017 & 545 & 113 & 4.8 \\
Outcome 2018 & 258 & 71 & 3.6 \\
Outcome 2019 & 302 & 148 & 2.0 \\
Forecast 2024 & 560 & & \\
\hline
\end{tabular}

According to the production schedule, the factory will prioritize the procurement of raw materials and fulfill the main order for the parent company in January of each year. Therefore, inventories catch up peak within period of March to June. Based on the Table 7, in the period 2017-2018, there was a sharp decrease in the storage rate towards reducing storage peaks, making inventory turnover faster to reduce storage costs for the factory. But in the scale of paper, peak of 2017 was chosen for base of calculation based on requirement of warehouse managers. Combining together with the designed production capacity of the factory -15 pallets per date used in cases of goods temporarily stored for objective reasons such as in an audit date or not in time for inventory. Therefore, new chosen storage peak is 560 pallets.

In the factory development orientation in next 05 years, the size of the future warehouse expansion is estimated to be about $20 \%$ in 2024 thanks to the application of expert method consulting the idea of production manager and owners of factory. The storage pallet amount 
will be also increased accordingly with the production capacity to $20 \%$, equivalent to 672 pallets.

\subsection{Layout}

The premises of the warehouse include:

- The outside design includes internal roads surrounding to the warehouse, the distance of the warehouse to adjacent factories and surrounding walls.

- The interior shows divisions of the warehouse space into different functional zones, related to storage racks and compartment walls.

The outside design is considered the requirement to take advantage of factory available equipment including floor area located inside the factory, internal roads... The expected warehouse will be located in the available land plot, not effected to the existing production buildings, has total land area is about $1,000 \mathrm{~m}^{2}$ in the behind of the factory, shown as below Figure 8.

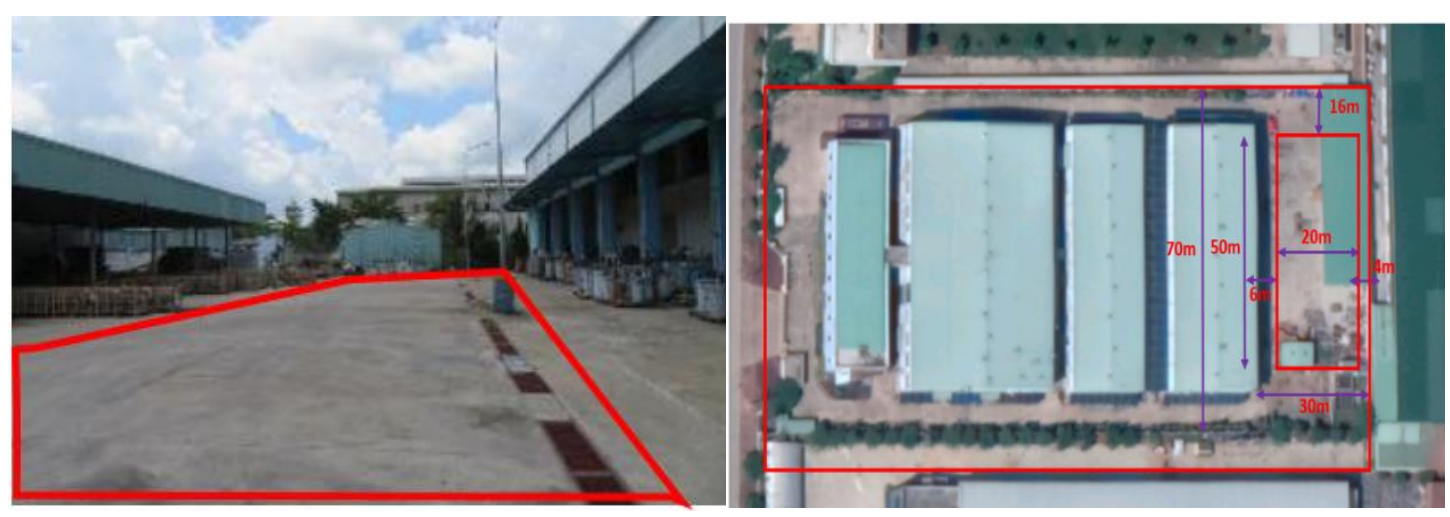

Figure 8 Floor area is planned for the designed warehouse

Based on the number of pallets found out above and the standard size of the type of wooden pallet the company is using, we calculate the required storage area:

$$
672 \times(1.2 \times 1)=807 \mathrm{~m}^{2}
$$

The detailed arrangement of the inside floor area of the warehouse depends on many relevant factors. Expected warehouse will be divided into 06 functional areas, the design trend in the article is to satisfy the requirements of Stakeholders about the floor area of functional zones such as: Administrative Office, Packing Zone, Forklift Parking and Re-charging Zone, then based on the daily production capacity of the factory, and the capacity of loading and unloading of trucks to calculate the floor area of Receiving Bay and Shipping Bay. The remaining area after subtracting the calculated functional areas is the main storage area where racks are equipped and stored the finished products. Detailed result is shown in Table 8.

The remaining area used for storage will be divided into 03 parts:

- $\quad$ Storage area with many racks which have calculation will be shown in Figure 9.

- Dimension of walkways, forklift paths.

- Ensure a safe distance to surrounding wall to prevent fire spreading hazard. 
Table 8 Floor area of functional zones of expected warehouse

\begin{tabular}{lc}
\hline \multicolumn{1}{c}{ Functional areas of the expected warehouse } & Floor area $\left(\mathbf{m}^{\mathbf{2}}\right)$ \\
\hline (a) Administrative Office & 6 \\
(b) Forklift Parking and Re-charging Zone & 20 \\
(c) Packing Zone & 28 \\
(d) Receiving Bay & 64 \\
(e) Shipping Bay & 64 \\
Total land area of expected warehouse & 1,000 \\
(f) Remaining area used for main storage & 818 \\
\hline
\end{tabular}

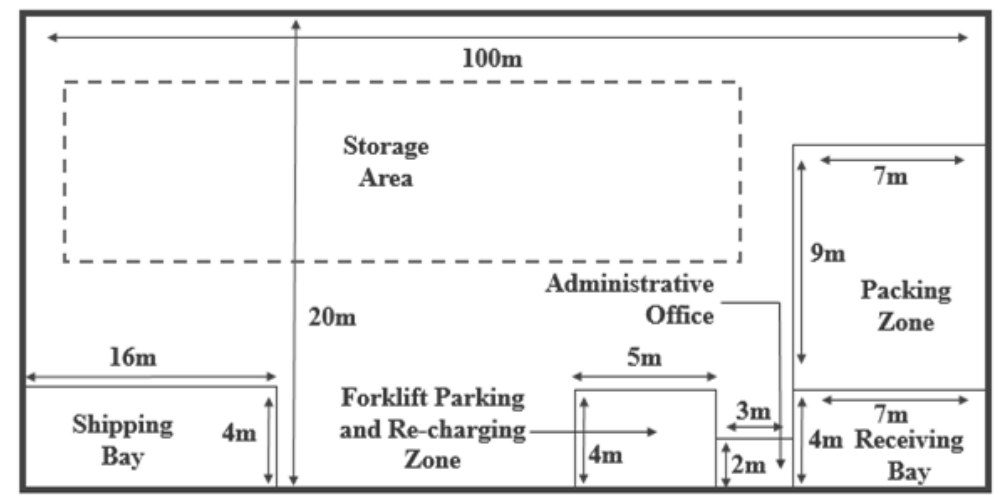

Figure 9 Simple layout of the warehouse functional zones

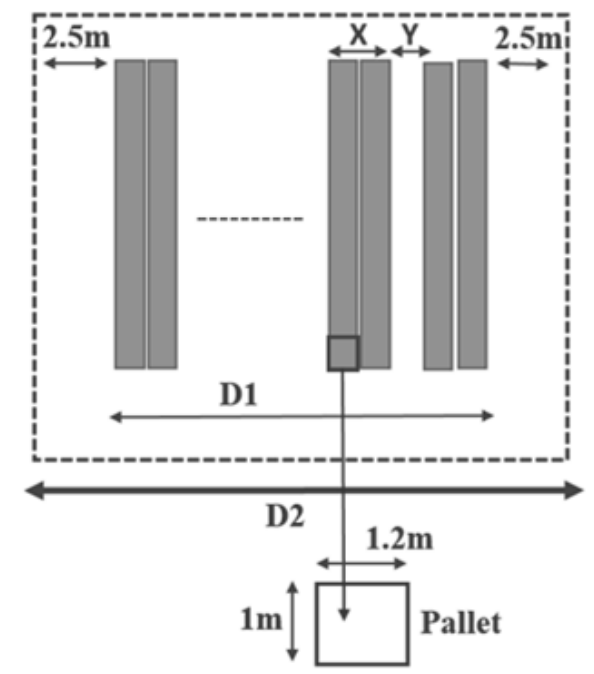

Figure 10 Simple diagram of shelf design problem

\subsection{Racks}

The scope of the paper is only to estimate the appropriate number of shelves and walkways, specific calculations will be more detailed when going into the practical application case, so the problem here is to simplify indicators such as shelf sizes, pallets between pallets, number of shelves counted as double shelves taken from both sides with the between aisle $-2.5 \mathrm{~m}$ (Figure 10). This method takes 01 edge of storage area with available size $(43 \mathrm{~m}$ or $16 \mathrm{~m})$ as a standard to calculate the number of shelves, the number of aisles then use the remaining edge to calculate the number of pallets on each shelf and the number of floors corresponding. The principle of estimation is that the number of floors will be inversely proportional to the shelf length, and no longer than the size limit. 


\subsubsection{Option 1 - Horizontal shelves}

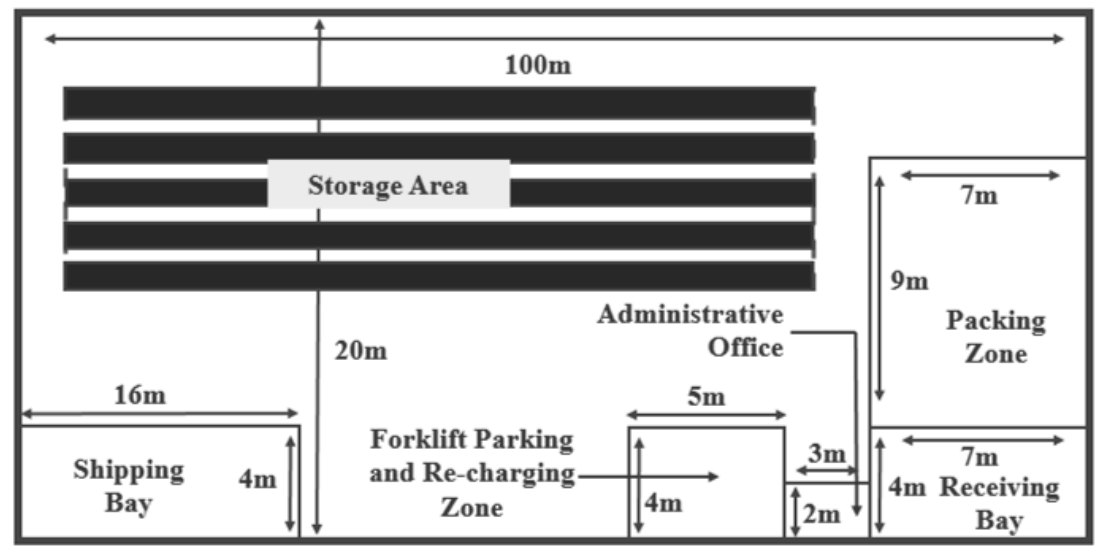

Figure 11 Design of horizontal shelves

Width of storage area: $20 m-4 m-(2.5 m \times 2)=11 m$.

- $\quad X$ - Number of shelves $\rightarrow$ Each shelf has a horizontal width of $1.2 \mathrm{~m}$, and with double shelf design $\rightarrow$ Shelf length $=2.4 X$.

- $\quad Y$ - Number of aisles $\rightarrow$ The width of the aisle is $2.5 \mathrm{~m} \rightarrow$ The total width of the aisle $=$ $2.5 Y$.

Replace the parameter into the variable, there are 04 shelves and 01 aisle (Figure 11).

\subsubsection{Option 2 - Vertical shelves}

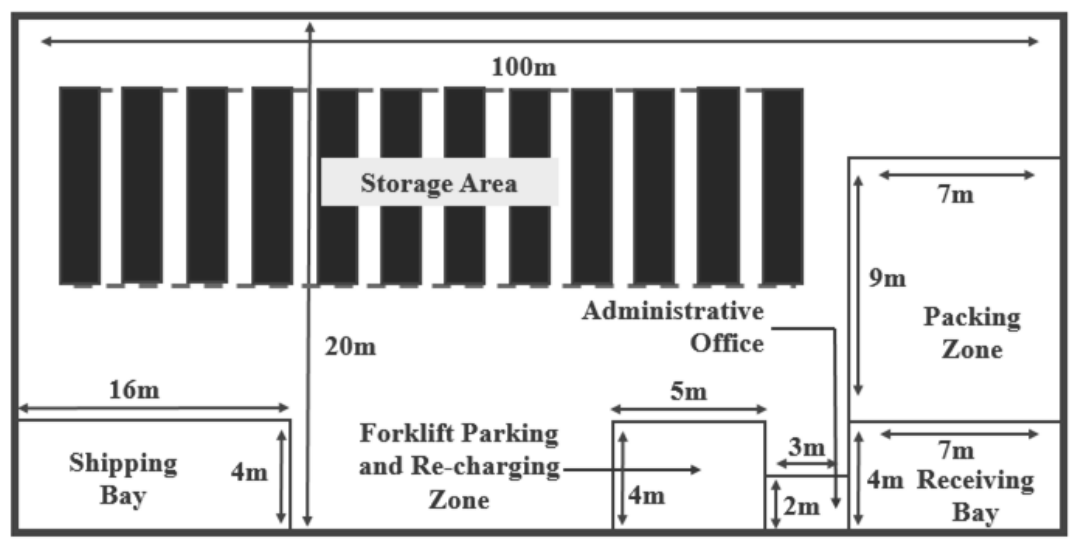

Figure 12 Design of vertical shelves

Width of storage area: $50 \mathrm{~m}-7 \mathrm{~m}-(2.5 \mathrm{~m} \times 2)=38 \mathrm{~m}$.

- $\quad X$ - Number of shelves $\rightarrow$ Each shelf box has a horizontal width of $1.2 \mathrm{~m}$, and with double shelf design $\rightarrow$ Shelf length $=2.4 X$.

- $\quad Y$ - Number of aisles $\rightarrow$ The width of the aisle is $2.5 \mathrm{~m} \rightarrow$ The total width of the aisle $=$ $2.5 Y$.

$$
\left\{\begin{array} { l } 
{ 2 . 4 X + 2 . 5 Y < 3 8 } \\
{ X = Y + 1 } \\
{ X > 1 , Y > 1 }
\end{array} \rightarrow \left\{\begin{array}{l}
X=7 \\
Y=6
\end{array}\right.\right.
$$

Replace the parameter into the variable, there is: 14 shelves and 06 aisles (Figure 12).

Calculate the remaining dimension of the shelf together with the corresponding number of floors, are shown in Table 9 below, based on the total number of pallets that need to contain 
672 pallets according to the calculation in Section 5.2. The number of pallets arranged in each shelf is calculated from the corresponding shelf length due to the width of the pallets is $01 \mathrm{~m}$ corresponding to 01 shelf. The number of shelves increases, the shelf length is decreased, until it is smaller than the previously calculated storage area size limit of $43 \mathrm{~m} \times 16 \mathrm{~m}$.

Table 9 Calculate shelf lengths corresponding to the number of floors

\begin{tabular}{lccccc}
\hline & 1 floor & 2 floors & 3 floors & 4 floors & Limited distance \\
\hline Option 1 & $168 \mathrm{~m}$ & $84 \mathrm{~m}$ & $56 \mathrm{~m}$ & $\mathbf{4 2 m}$ & $43 \mathrm{~m}$ \\
Option 2 & $48 \mathrm{~m}$ & $24 \mathrm{~m}$ & $16 \mathrm{~m}$ & $\mathbf{1 2 m}$ & $16 \mathrm{~m}$ \\
\hline
\end{tabular}

The loading and unloading time need to be shortened as much as possible, deducing the distance the forklift moves each time it needs to be shortened as much as possible. With Option 2, the distance to the warehouse doors is also shortened due to more moving paths. So, Option 2 has 14 rows of shelves and 06 aisles, each row has 4 floors, each floor contains 12 pallets.

Compared with the requirement that the building height of the warehouse is equal to the adjacent factories which are actually measured to be $12 \mathrm{~m}$, the height of 3 floors of $8 \mathrm{~m}$ is also suitable.

\section{DETAILED DESIGN}

\subsection{Construction}

The warehouse will be constructed in the floor area of $1,000 \mathrm{~m}^{2}$, height of $12 \mathrm{~m}$, a steel core column, a standardized V-shaped steel of beam, box type of shape, a 100mm brick wall built $2 \mathrm{~m}$ high, the upper part using a corrugated iron wall, a tole roof, combined with skylight panels in some positions to make advantages of the natural daylight and limit power consumption.

Because the new warehouse is located on the old ground of the existing warehouse with the existing concrete foundation, according to the information of the leadership board, it has saved about $20 \%$ of the construction value.

\subsection{Facilities}

Based on the calculation results as in section 5.2, we can refer to the design of rack system on the market and choose the appropriate type with the specifications and prices which are considered (Table 10). About pallets, there are some options in considering on Table 11.

Table 10 Shelves' specifications

\begin{tabular}{|c|c|c|}
\hline Products & Technical specification & Price \\
\hline $\begin{array}{l}\text { Selective } \\
\text { Shelves }\end{array}$ & $\begin{array}{l}\text { Load capacity: } 3500 \mathrm{~kg} / \text { Pallet. } \\
\text { Leg frame: Use omega foot to punch holes } \\
\text { Counter tops: Used Cross bar, tole, mesh, or plywood, } \\
\text { MDF, Okal ... } \\
\text { Method of loading: Forklift types } \\
\text { Standard paint colors: Blue - Orange - Gray (can change } \\
\text { colors according to customer requirements) } \\
\text { Product warranty period: } 07 \text { years }\end{array}$ & $\begin{array}{l}1,0 \text { mil VND per unit } \\
\rightarrow 672 \text { VND for } \\
\text { amount of rack } \\
\text { system } \approx 28,600 \\
\text { USD }\end{array}$ \\
\hline
\end{tabular}


Table 11 Pallets' specifications

\begin{tabular}{|c|c|c|c|}
\hline Option No. & Product name & Technical Specification & $\begin{array}{l}\text { Price (mil VND } \\
\text { per unit) }\end{array}$ \\
\hline 1 & $\begin{array}{l}\text { Wooden Pallet } 1,1 \times \\
1,1 \mathrm{~m} \text { (opening face) }\end{array}$ & $\begin{array}{l}\text { - Wooden pallet } \\
\text { - Size: } 110 \times 110 \times 12 \mathrm{~cm} \\
\text { - Load: Over } 1000 \mathrm{~kg}\end{array}$ & 0.30 \\
\hline 2 & $\begin{array}{l}\text { New trash wood } \\
\text { pallet }- \text { new } 100 \% \text { : } \\
1 \mathrm{~m} \times 1,2 \mathrm{~m}\end{array}$ & $\begin{array}{l}\text { - Wooden pallet has } 04 \text { loading sides } \\
\text { - Size: } 1 \mathrm{~m} \times 1,2 \mathrm{~m} \times 13 \mathrm{~cm} \text {. } \\
\text { - Load: Over } 1500 \mathrm{~kg}\end{array}$ & 0.32 \\
\hline 3 & $\begin{array}{l}\text { Wooden Pallet } 1,1 \times \\
1,3 \mathrm{~m} \text { (hunched legs) }\end{array}$ & $\begin{array}{l}\text { - Wooden pallet } \\
\text { - Size: } 110 \times 130 \times 15 \mathrm{~cm} \\
\text { - Load: Over } 1000 \mathrm{~kg}\end{array}$ & 0.35 \\
\hline
\end{tabular}

Option 1 - Wood Pallet has been chosen based on the cheapest price, meet the standards of weight and quality at the supplier, also in current used in the survey premise. Amount order is in batch of 1,000 units, so total price of pallets is about 300 million VND, equivalent to 12,800 USD.

Using Sketchup Software developed by Trimble Inc. - a 3D modeling computer program for a wide range of drawing applications such as architectural, interior design, landscape architecture, civil and mechanical engineering... A warehouse model has been built to help stakeholders easily visualize the details of the warehouse. The stimulated warehouse layout was shown as Figure 13, Figure 14 and Figure 15 below.

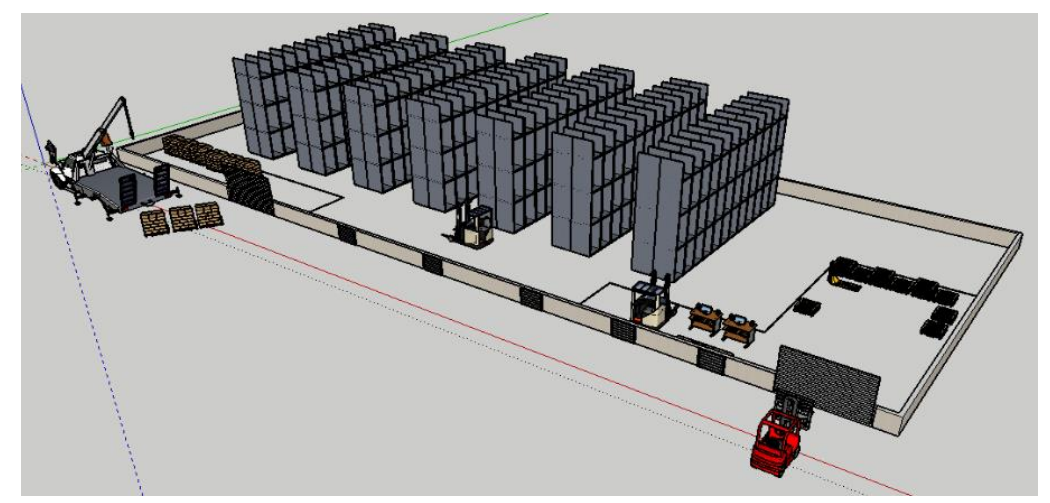

Figure 13 Panoramic background of warehouse

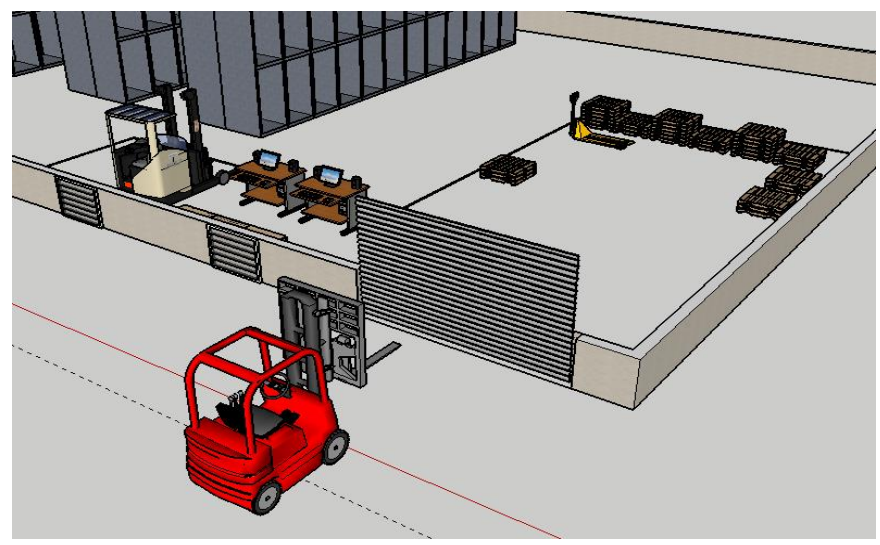

Figure 14 Receiving Zone and Packing Zone of warehouse 


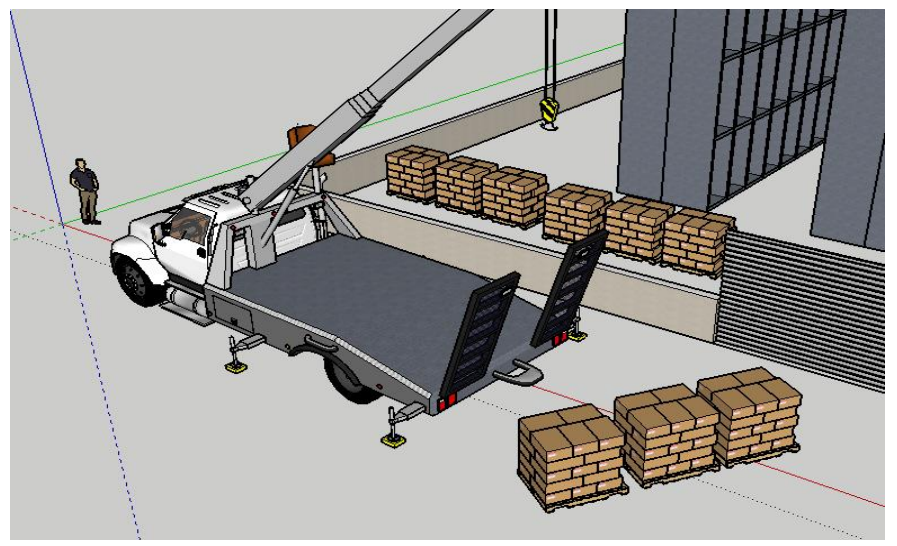

Figure 15 Shipping Zone of the warehouse

\section{VALIDATION}

The warehouse design alternative is based on the understanding of operational status of current warehouse including the normal operations such as receiving, ordering, picking orders, packaging and shipping processes. It also includes predictions for unexpected situations and future production expansion scenarios. The warehouse data collected in various forms is considered as basis for calculating the storage capacity and ancillary supports. The estimated cost for the design is also fully calculated. The results of design alternative using system engineering method combined together with new research on warehouse design process for fast-growing factories. After being presented, there was a high appreciation of BOD for its conformity with general plant conditions, requirements of related departments, and the correspondence between theory and practices. It will be a consideration in practice when conducting warehouse construction in the future.

\section{CONCLUSION \& RECOMMENDATION}

From the views presented above, it can be seen that the ability to build this warehouse is feasible and highly referenced for similar projects have same occupancies. The design process is carried out in the order of system engineering procedure ensuring the following factors:

- Interested and meet most of the requirements of Stakeholders from storage capacity, moving space, administrative area

- Proposing to Board of Directors of factory the basic findings of the future construction objects - finished product warehouse of the factory at the current time. And considering the future development of the factory includes both production and storage capacity.

- Applicating and combining modern warehouse development studies with the traditional ways of system engineering process thereby suggesting similar design applications.

All of these above views are aimed at developing knowledge of system engineering and suggesting the available design which is very effective in case of applying in the actual process of designing the facilities of the enterprise in the future to save time, effort, ensure technical factors, safety standards and labor regulations.

\section{ACKNOWLEDGMENTS}

This research is funded by Ho Chi Minh University of Technology (HCMUT), VNU-HCM, under grant number BK-SDH-2020-1870183. 


\section{REFERENCES}

[1] Kossiakoff, A., Sweet, W. N., Seymour, S. J., \& Biemer, S. M. (2011). Systems engineering principles and practice (Vol. 83). John Wiley \& Sons.

[2] Bartholdi III, J. J., \& Hackman, S. T. (2017). Warehouse \& Distribution Science Release 0.98. The Supply Chain \& Logistics Institute, Georgia Institute of Technology, Atlanta, USA

[3] Christopher, M. (2016). Logistics \& supply chain management. Pearson UK.

[4] Ghiani, G., Laporte, G., \& Musmanno, R. (2004). Introduction to logistics systems planning and control. John Wiley \& Sons.

[5] Kay, M. G. (2012). Material handling equipment. Fitts Dept. of Industrial and Systems Engineering North Carolina State University, 65.

[6] Phan Thanh Lam (2015). Warehouse Management Handbook. Vietnam, Women Publishing House

[7] Le Ngoc Quynh Lam (2013). Location and layout design of industrial system. Vietnam, National University Press of Ho Chi Minh City

[8] Felix Geuken \& Louise Jager (2017), Developing a Warehouse Layout Design Framework for Fast Growing Companies - A Case Study at Oatly AB. Sweden, Department of Industrial Management and Logistics, Faculty of Engineering, Lund University. 